DOI: $10.17805 / g g z .2017 .6 .2$

\title{
Публикации «Горизонтов гуманитарного знания» за 2017 год: итоги первого года
}

В. А. Дугин, С. В. Луков

Московский гуманитарный университет

В статье характеризуются публикации, включенные в 2017 г. в электронный журнал «Горизонты гуманитарного знания». Tемы номеров определили направленность опубликованных статей на актуальную для гуманитарных наук проблематику. В статье представлены предметные области, в которых публикации журнала продвигают вперед гуманитаристику, дан алфавитный указатель статей журнала.

Ключевые слова: гуманитарные науки; журнал «Горизонты гуманитарного знания»; тезаурусный подход; шекспиросфера

\section{Publications of "The Horizons of Humanities Knowledge": The Results of the First Year V. A. Dugin, S. V. Lukov Moscow University for the Humanities}

The article characterizes the contributions published in the "The Horizons of Humanities Knowledge" electronic journal in 2017. The topics of the issues determined the focus of the published articles on the urgent problems for the humanities. The article presents the scope, which the publications of the journal advance the humanities in, and contains the index of articles.

Keywords: humanities; "The Horizons of Humanities Knowledge" journal; thesaurus approach; Shakespearean sphere

\section{ВВЕДЕНИЕ}

В 2017 г. электронное издание «Информационный гуманитарный портал “Знание. Понимание. Умение”» было преобразовано в электронный журнал «Горизонты гуманитарного знания», который в этом новом качестве был зарегистрирован Роскомнадзором РФ и вслед за этим его номера стали фиксироваться в Российском индексе научного цитирования - РИНЦ. В силу этого в декабре 2017 г. в 
РИНЦ отмечено, что журнал выходит с 2007 г., его импакт-фактор равен 0,141, в нем размещено 734 статьи, вышло 78 выпусков, отмечено, что он индексируется в международной базе CrossRef. Конечно, эти характеристики относятся к предшественнику «Горизонтов...», некоторые (например, импакт-фактор) рассчитываются только для журналов, выходящих более двух лет. Но новый журнал и в самом деле не так нов, многие темы в нем продолжаются чуть ли не с первого номера 2007 г., т. е. 10 лет. Очень важно, что он, как и его предшественник, развивает тезаурусный подход, ставший инновационным в гуманитарном знании, выразителем его субъектной организации и занявший свое место среди субъектно-ориентированных методологических средств гуманитаристики (к которой справедливо относить также и такие социальные науки, как социология, поскольку они выражают значимую сторону жизнедеятельности человека в обществе).

В чем же новизна «Горизонтов...»? Вышедшие 6 номеров электронного журнала в 2017 г. позволяют утверждать, что не только изменилось его название, но и курс определенно сдвинулся в сторону науки будущего и общества будущего, хотя темы прошлого и настоящего остаются актуальными для этого издания (Гаврилова, Колесниченко, 2017; Ильин, 2017ab; Науменко, 2017; Торос, Колесниченко, 2017). В первой статье обновленного журнала его главный редактор - известный социолог, культуролог, философ (по данным РИНЦ, он входит в первую сотню наиболее цитируемых российских авторов по таким группам наук, как философия, социология, культурология), но также и филолог, историк психологии, специалист по социальному проектированию, государственной молодежной политики и т. д. - профессор Вал. А. Луков предполагает: «Посмотрим, насколько в трудах исследователей, особенно молодых, найдут отражение не просто темы гуманитарного знания, а их горизонтов - того, что видится в перспективе, нередко отдаленной...» (Луков, 2017a).

\section{ОБЩИЕ ВОПРОСЫ «ГОРИЗОНТОВ ...»}

Номера «Горизонтов...» посвящены определенным темам. Они по вышедшим номерам таковы: (1) «Горизонты теории и практики воспитания. Потенциал педагогической классики»; (2) «Горизонты комплексного исследования человека: пограничные зоны человече- 
ского существования»; (3) «Горизонты будущего: аспект экологии культуры» (эта тема представлена в № 3-4 журнала); (4) «Горизонты науки»; (5) «Тезаурусная сфера и шекспиросфера». В рубрике «Общие вопросы», открывающие каждый номер, выявлены основные параметры, к которым относятся собранные статьи - в основном представленные как монодисциплинарные (в отличие от междисциплинарности статей вводного раздела).

Так, например, построен второй номер. Вводная статья Вал. А. Лукова (Луков, 2017b), в которой субъект жизнедеятельности представлен через его понимание тех сторон жизни, которые им самим рассматриваются как пограничные в зависимости от эпохи и культурных кодов, задает тему уже своим заголовком «Пограничные зоны человеческого существования и их осознание человеком». Для раскрытия этой темы автор применяет тезаурусный подход, который, по его словам, «позволяет увидеть пограничные зоны человеческого существования как переход от одного состояния к другому, которое понимается в пределах субъектной организации знания» (там же: 11). Эта тема затем рассматривается в аспектах антропологии (Алехнович, 2017; Завьялова, 2017), истории (Науменко, 2017), политологии (Ильин, 2017а), социологии (Тихомиров, Кисткина, 2017), философии (Ярославцева, 2017; Луков С., 2017а).

Третий и четвертый номера журнала показывают оригинальный подход к экологии культуры. В разделе «Общие вопросы» здесь стоят статьи «Экология культуры и тезаурусная трактовка будущего» Вал. А. Лукова (Луков, 2017c), «Будущее как объект философско-педагогического осмысления» Я. С. Турбовского (Турбовской, 2017), «Классическая, неклассическая и постнеклассическая культуры: опыт новой типологии» А. Я. Флиера (Флиер, 2017). В продолжающем тему номере стоят статьи «Современные императивы коэволюции человека и природы» А. А. Горелова и Т. А. Гореловой (Горелов, Горелова, 2017), «Человек этнический: проблемы конструирования» Ч. К. Ламажаа (Ламажаа, 2017). Уже видно, что междисциплинарность в союзе с тезаурусным подходом дают здесь несколько иной взгляд на экологию культуры, чем обозначился в гуманитарных науках в концепции Д. С. Лихачева. Следующие статьи в сферах истории (Гаврилова, Колесниченко, 2017; Торос, Колесниченко, 2017), культурологии (Калита, 2017; Меняева, Невелева, 2017; Сальникова, 2017; Кузнецова, 2017; Кулешова, 2017; Именнова, 2017), 
музееведения (Гудима, 2017), социологии (Тихомиров, Сиднева, 2017), философии (Козьякова, 2017; Кожаринова, 2017; Иванова, 2017; Макаревич, 2017) не всегда построены как новая интерпретация экологии культуры, но в совокупности и в определенном единстве со статьями из раздела «Общие вопросы» такая интерпретация возникает.

Особого внимания в этом отношении заслуживает статья профессора, известного философа культуры и специалиста по теории и истории культуры Т. Ф. Кузнецовой «Субъектность как атрибут экологии культуры» (Кузнецова, 2017). В этой статье субъектность трактуется как «порождаемое активностью субъекта (индивида или группы) свойство культурного объекта» (там же: 25). Это свойство Т. Ф. Кузнецовой показано в процессе становления от частного случая, соединения случайных обстоятельств рождения культурного объекта, где субъект в полной мере проявляет свои качества (интеллектуальные, эмоциональные, а также ведущие к созданию образа), до «полн[ого] отрыв[а] культурного феномена от субъекта с его индивидуальными характеристиками и превращения его (феномена) в культурную константу» (там же: 28). Это движение, по мнению автора, и составляет феномен экологии культуры, а субъектность образует ее атрибут. Методологическая сторона этого феномена раскрывается в тезаурусном подходе. Статья продолжает характеристику экологии культуры, которую можно найти в статьях из раздела «Общие вопросы», а также в разделе «Из архива Института фундаментальных и прикладных исследований», где помещена ранее не замеченная и не прочтенная в этом ключе статья видного культуролога и филолога Вл. А. Лукова (1948-2014) «Экология культуры и тезаурусные технологии преодоления глобализационной энтропии знаний» (Луков Вл., 2017).

\section{ГОРИЗОНТЫ НАУКИ}

В обновленном журнале первого года выпуска много места посвящено перспективам гуманитарных наук. Кроме того, что этой теме посвящен № 5 журнала, и в других номерах это одна из приоритетных позиций. Представить перспективы науки - задача крайне сложная, если ей посвящено монографическое издание, но она упрощается, если новации соединены с уже устоявшимися подходами, которые через какое-то время могут быть пересмотрены и ока- 
заться в тени новаций, но потом вновь могут возродиться в новом для них материале. В этом ключе решены и задачи в данном электронном издании. Предметный указатель, который мы составили на основе ключевых слов, выделенных в каждой статье, показывает широту охвата новых тем и в то же время единство уже принятой в научном сообществе терминологии с терминологией, только рождающейся в гуманитарных науках или приобретающей в наше время новый смысл. В предметном указателе выделены около 200 слов (в ряде случаев правильнее сказать групп слов и словосочетаний, поскольку использовались упрощения, подобные факторному анализу в социологии). Приведем полученный результат в алфавите выделенных слов и словосочетаний и обозначением тех статей, в которых они появились как существенные для самих авторов:

автономный автомобиль для райдшеринга - Луков С., 2017b; андроид - Луков С., 2017b; апроприация - Гайдин, 2017b; ареал - Гаврилова, Колесниченко, 2017; арете - Гаврилова, Колесниченко, 2017; атомная война - Сальникова, 2017; аудит политический - Борисов, 2017; аутопоэзис человека - Ярославцева, 2017; безопасность национальная - Луков С., 2017b; «Бесплодные усилия любви» - Макаров, 2017; биосоциология - Юдин, 2017;

будущее - Турбовской, 2017;

Бурдьё П. - Лисович, 2017;

вариативность - Макаров, 2017;

ватцап - Луков С., 2017b;

виадук - Гаврилова, Колесниченко, 2017;

викиликс - Луков С., 2017b;

возрастные группы - Луков, 2017b;

воспитание - Иванова, 2017; Луков С., 2017а;

Восточная Азия - Канарш, 2017;

выбор - Завьялова, 2017;

высшее образование, трудности адаптации в вузе, выпускники вузов, проблемы их трудоустройства - Луков В., Луков С., 2017; Тихомиров, Сиднева, 2017;

габитус - Пинчук, 2017; Лисович, 2017; 
гармония - Меняева, Невелева, 2017;

Гас Ван Сент - Гайдин, 2017a;

глобализация - Гайдин, 2017b; Луков Вл., 2017; Турбовской, 2017 ;

Гнедич Т. Г. - Гайдин, 2017c;

Грузия - Ильин, 2017b;

гуманитарное знание, гуманитарные науки, перспективы гуманитарных наук - Луков, 2017ad;

гуманитарное сопротивление - Макаревич, 2017;

действительность - Алехнович, 2017;

демократия - Ильин, 2017ab;

дети-индиго - Юдин, 2017;

деятельность - Алехнович, 2017;

динамичность коммуникаций - Ярославцева, 2017;

доклад князя М. Воронцова - Науменко, 2017;

единство - Меняева, Невелева, 2017;

загрязнение - Сальникова, 2017;

Запад - Канарш, 2017;

заповедники - Кулешова, 2017;

Зенкевич М. А. - Захаров, 2017;

идентичность социальная, национальная - Емельянова, Дробышева, 2017; Гайдин, 2017b;

идеология, идеологическое многообразие - Макаревич, 2017;

«Изображая жертву» - Гайдин, 2017а;

императив эволюционный, императив экологический - Горелов, Горелова, 2017;

императрица Екатерина II - Науменко, 2017;

инициативность - Шонин, 2017;

интеллект искусственный - Луков, Погорский, 2017; Луков C., 2017b;

интерес, познавательный интерес, уровни познавательного интереса - Шонин, 2017;

Ирак - Ильин, 2017b;

искусство - Иванова, 2017;

историческое сознание - Емельянова, Дробышева, 2017;

история Древнего Рима, римский гражданин - Торос, Колесниченко, 2017;

калокагатия - Гаврилова, Колесниченко, 2017; 
«Камеральное описание» - Науменко, 2017;

капитал культурный - Пинчук, 2017;

капитализм - Канарш, 2017;

Карибский кризис - Меняева, Невелева, 2017;

картина мира культурная - Луков, Погорский, 2017;

катастрофа - Сальникова, 2017;

киберпространство - Луков С., 2017b;

кинематограф современный - Гайдин, 2017a;

кино мировое, кино советское - Гайдин, 2017a; Сальникова, 2017; Кузьмичев, 2017;

классика - Флиер, 2017;

климат - Гаврилова, Колесниченко, 2017;

Козинцев Г. М. - Кузьмичев, 2017;

колонизация - Гаврилова, Колесниченко, 2017;

консенсус - Меняева, Невелева, 2017;

константа культурная - Кузнецова, 2017;

конструктивизм - Ламажаа, 2017;

контроль масс глобальный - Макаревич, 2017;

концепт - Луков, 2017c;

коэволюция - Горелов, Горелова, 2017;

Крым - Науменко, 2017; Ильин, 2017а;

культур типология- Флиер, 2017;

культура - Завьялова, 2017; Иванова, 2017; Кожаринова, 2017;

Козьякова, 2017; Флиер, 2017;

культурология - Гудима, 2017; Кузнецова, 2017; Луков, 2017с; Луков Вл., 2017;

культурология субъектная - Луков, 2017b;

ландшафт, ландшафты культурные - Гаврилова, Колесниченко, 2017; Именнова, 2017; Кулешова, 2017;

лицемерие - Ильин, 2017b;

личность - Алехнович, 2017;

ложь - Ильин, 2017b;

Луков Вл. А. - Кузнецова, 2017;

«Макбет» — Лисович, 2017;

малазийский Боинг - Ильин, 2017a;

массовая культура - Гайдин, 2017b;

ментальность - Емельянова, Дробышева, 2017; Торос, Колесниченко, 2017; 
«Мера за меру» — Захаров, 2017;

метафора, метафоризация - Именнова, 2017; Луков, 2017d;

мир виртуальный, мир жизненный, мир социальный - Алехнович, 2017; Ярославцева, 2017;

мировая культура - Гайдин, 2017bc;

мировоззрение - Флиер, 2017;

мифотворчество - Гаврилова, Колесниченко, 2017;

модернизация - Канарш, 2017;

«Мой личный штат Айдахо» - Гайдин, 2017a;

молодежь - Луков, 2017b; Луков С., 2017a; Юдин, 2017;

мотивационная сфера личности - Комолов, 2017;

мотивационные диспозиции - Комолов, 2017;

музееведение - Гудима, 2017;

музей, музеи-заповедники, музеи российские - Гудима, 2017;

Именнова, 2017; Кулешова, 2017;

мультикультурализм - Канарш, 2017;

мусор, «окультуривание» и «эстетизация» отходов - Кожаринова, 2017;

наследие всемирное, континуум наследия - Кулешова, 2017;

наука, фундаментальная, прикладная, разработки, эффективность науки, показатели науки - Башина, Николенко, 2017;

национальная культура - Гайдин, 2017bc;

национально-психологические особенности, национальный характер, национальный менталитет - Канарш, 2017;

национальные парки - Кулешова, 2017;

неклассические и постнеклассические культуры, неклассическая парадигма - Козьякова, 2017; Флиер, 2017;

Некор Л. С. - Гайдин, 2017c;

неокантианство, Баденская школа - Луков, 2017d;

неошекспиризация - Июдин, 2017;

Новороссия - Науменко, 2017;

обожествление - Иванова, 2017;

образ - Иванова, 2017;

образование, образования система, образовательные практики, современные проблемы обучения - Луков В., Луков С., 2017; Луков, Погорский, 2017; Пинчук, 2017; Турбовской, 2017;

OB3, студенты с ОВ3 - Комолов, 2017; Семериков, 2017;

окружающая среда, городская среда - Калита, 2017; Козьяко- 
ва, 2017; Сальникова, 2017;

олицетворение - Именнова, 2017;

онлайн-курсы - Луков, Погорский, 2017;

онтология предмета - Ярославцева, 2017;

особо охраняемые природные территории - Кулешова, 2017;

охрана природы, охраны зоны - Калита, 2017; Кулешова, 2017 ;

память коллективная - Емельянова, Дробышева, 2017;

первокурсники - Луков В. А., Луков С., 2017;

переводы, Шекспир в русских переводы, постсоветские переводы Шекспира - Гайдин, 2017bc; Захаров, 2017; Лисович, 2017; Макаров, 2017;

переписка в «Литпамятниках» - Науменко, 2017;

печатное издание - Луков С., 2017a;

пограничная ситуация, пограничные состояния человека - Завьялова, 2017; Луков, 2017b;

поколения, поколение X, поколение «шестидесятников»Емельянова, Дробышева, 2017;

политические технологии избирательной кампании - Борисов, 2017;

политология - Борисов, 2017;

полиэтничность - Канарш, 2017;

постмодерн - Козьякова, 2017;

потребительство - Горелов, Горелова, 2017;

принципат - Торос, Колесниченко, 2017;

природа, объекты природного наследия, природное и культурное наследие, - Горелов, Горелова, 2017; Иванова, 2017; Калита, 2017; Козьякова, 2017; Кулешова, 2017;

присутствие - Алехнович, 2017;

проект - Алехнович, 2017;

проект VVV - Захаров, 2017;

пропаганда - Ильин, 2017a;

пространство - Именнова, 2017;

процесс, процесс обучения, процесса онтология, процесс политический - Борисов, 2017; Шонин, 2017; Ярославцева, 2017;

психология - Луков, 2017е;

публичное пространство - Козьякова, 2017;

Пушкин А. С. - Захаров, 2017; 
развитие социальное - Канарш, 2017;

религия - Иванова, 2017;

рецепция - Гайдин, 2017b;

риторика - Ильин, 2017b;

«Ромео и Джульетта» - Июдин, 2017;

Российская Империя - Науменко, 2017;

Россия - Ильин, 2017b; Канарш, 2017;

русская классическая литература - Макаревич, 2017;

русская культура - Науменко, 2017;

самобытие - Алехнович, 2017;

Светлейший князь Потемкин-Таврический - Науменко, 2017;

семья, межпоколенческий аспект - Пинчук, 2017;

Серебренников К. С. - Гайдин, 2017a;

символ - Именнова, 2017;

синдром Бивиса и Батхеда - Луков, 2017d;

синтез - Луков, Погорский, 2017;

Сирия - Ильин, 2017b;

современная культура - Гайдин, 2017bc;

согласие, социокультурная парадигма согласия, несогласие Меняева, Невелева, 2017;

Сорока О. П. - Захаров, 2017;

социология культуры - Луков, 2017de;

социология молодежи - Луков, 2017d; Луков В. А., Луков С., 2017 ;

сравнительный анализ - Гайдин, 2017c; Захаров, 2017; Лисович, 2017;

стратегии переводческие - Макаров, 2017;

страх - Сальникова, 2017;

студенты условно здоровые - Семериков, 2017;

субъект; субъектность - Кузнецова, 2017;

счастье субъективное - Семериков, 2017;

США - Ильин, 2017b;

театр советский, МХАТ, Малый театр - Кузьмичев, 2017;

тезаурусная сфера - Борисов, 2017; Луков, 2017е;

тезаурусный подход - Борисов, 2017; Луков, 2017abcde; Луков

С., 2017ab; Кузнецова, 2017; Луков В. А., Луков С., 2017; Луков Вл., 2017; Луков, Погорский, 2017;

теория поля в гуманитаристике - Луков, 2017е; 
технологии организации информации - Луков Вл., 2017;

трансгуманизм - Юдин, 2017;

трансформация - Иванова, 2017;

тревожность - Комолов, 2017; Семериков, 2017;

триада греческая - Гаврилова, Колесниченко, 2017;

«Троил и Крессида» - Гайдин, 2017c;

трэш-арт - Кожаринова, 2017;

удовлетворенность жизнью - Семериков, 2017;

Украина - Ильин, 2017ab;

фантастика - Сальникова, 2017;

Федоров А. М. - Гайдин, 2017c;

философия культуры - Луков, 2017cde;

философия образования - Турбовской, 2017;

Флоря А. В. - Гайдин, 2017c;

Фукуяма Ф. - Ильин, 2017a;

ценности, ценностное единство, ценностные ориентации -

Емельянова, Дробышева, 2017; Луков С., 2017b; Макаревич, 2017;

человек, человек этнический - Ламажаа, 2017; Ярославцева, 2017;

Черноморский флот - Науменко, 2017;

Шекспир в России, в СССР, юбилеи Шекспира - Гайдин, 2017b; Июдин, 2017; Кузьмичев, 2017;

Шекспир в современной культуре, в современном кино, в Интернете и молодежная культура - Гайдин, 2017ас; Июдин, 2017;

Шекспир У. - Гайдин, 2017abc; Захаров, 2017; Июдин, 2017; Кульмичев, 2017; Лисович, 2017; Макаров, 2017;

шекспиризация - Гайдин, 2017b;

шекспиризм - Гайдин, 2017b;

Шекспировские чтения - Кузьмичев, 2017;

шекспиросфера - Гайдин, 2017ab; Июдин, 2017;

Щепкина-Куперник Т. - Захаров, 2017;

экзистенция - Алехнович, 2017;

экологический кризис - Горелов, Горелова, 2017; Тихомиров, Кисткина, 2017;

экологическое поведение, сознание - Тихомиров, Кисткина, 2017;

экология - Гаврилова, Колесниченко, 2017; Иванова, 2017; Калита, 2017; Козьякова, 2017; Сальникова, 2017; Тихомиров, Кисткина, 2017;

экология культуры - Козьякова, 2017; Кузнецова, 2017; Луков, 
2017с; Луков Вл., 2017;

экосистемы - Ярославцева, 2017;

экспертиза гуманитарная — Ламажаа, 2017;

экспозиция - Именнова, 2017;

электронное издание - Луков, 2017a;

эмоциональная направленность - Семериков, 2017;

энтропия знаний - Луков Вл., 2017;

этничность - Ламажаа, 2017;

этнос - Ламажаа, 2017;

языковая единица - Завьялова, 2017;

Япония - Завьялова, 2017;

Version Variation Visualization - Гайдин, 2017c; Захаров, 2017; Лисович, 2017; Макаров, 2017.

Такова полученная картина, она включает более 200 наименований предметов исследования. Из нее видны основные области науки, которые рассматриваются авторами как перспективные. К ним, в частности, относятся культурология, политология, экология и др., появившиеся в XX в. Но есть и более давние гуманитарные науки, в том числе история, психология, социология, философия и др., обычно как отрасли этих наук (философия культуры, социология молодежи и др.) или совокупности идей, составивших теории (например, теорию поля). Есть и относительно недавние или совсем новые научные образования (биосоциология, трансгуманизм, шекспиросфера и т. д.). Очевидно, что предметные области шести номеров журнала, вышедших в течение одного года, не могут представить перспективы гуманитарных наук в их полноте, но показывают направление поиска. Особый интерес представляет шекспиросфера как еще только формирующаяся отрасль науки, сразу становящаяся междисциплинарной и не уходящей только в русло шекспироведения. В № 6 «Горизонтов...» этому направлению посвящены статьи Б. Н. Гайдина, Н. В. Захарова, Д. А. Июдина, А. И. Кузьмичева, И. И. Лисович, В. С. Макарова (Гайдин, 2017bc; Захаров, 2017; Июдин, 2017; Кузьмичев, 2017; Лисович, 2017; Макаров, 2017), составившие вместе целый раздел номера. Здесь находится место и для традиционных тем шекспироведения (переводы, их сопоставление и т. д.), и для формирующихся в информационном обществе тем «Русский Шекспир», «Мир Шекспира» и т. д., которые могут быть представлены только с использованием возможностей электронных ресурсов. 


\section{ЗАКЛЮЧЕНИЕ}

Электронный журнал «Горизонты гуманитарного знания» начал свой путь в 2017 г. Уже в первых номерах представлены позиции ведущих сотрудников, аспирантов, студентов не только Московского гуманитарного университета, при котором журнал создан, но и представителей таких научных и образовательных организаций, как Институт философии РАН, Институт психологии РАН, ИНИОН РАН, Московский педагогический государственный университет, Российский экономический университет им. Г. В. Плеханова, Российская академия народного хозяйства и государственной службы при Президенте РФ, Православный Свято-Тихоновский гуманитарный университет, Государственный институт искусствознания, Высшее театральное училище (институт) им. М. С. Щепкина, Уральский федеральный университет им. первого Президента России Б. Н. Ельцина, Петрозаводский гуманитарный университет, Омский государственный педагогический университет, Челябинский институт культуры и др. Журнал, таким образом, стремится показать перспективы гуманитарного знания с различных точек зрения.

В журнале некоторые подходы представлены более основательно, чем другие. В первую очередь основательность относится к методологическому тезаурусному подходу, который сформировался в своих важных чертах в Институте фундаментальных и прикладных исследований МосГУ. Тезаурусный подход обозначен в 13 статьях журнала как основной (т. е. более чем в $28 \%$ публикаций). Но это не значит, что только этот подход приветствуется в данном электронном издании. Журнал видит перспективы гуманитарных наук именно в разнообразии их тематики и методологии исследования. Одним из непременных оснований журнала, как представляется из итогов публикации им статей в первый год издания, является преодоление, где это возможно и целесообразно, монодисциплинарности в сфере гуманитаристики. Междисциплинарность и путь к трансдисциплинарности будут, по всей видимости, характеризовать его и в последующие годы. 


\section{СПИСОК ЛИТЕРАТУРЫ}

(алфавитный указатель статей журнала «Горизонты гуманитарного знания» за 2017 год)

Алехнович, А. С. (2017) Самобытие человека в социальном мире: экзистенциально-антропологический подход [Электронный pecypc] // Горизонты гуманитарного знания. № 2. URL: http://journals. mosgu.ru/ggz/article/view/458 (дата обращения: дд.мм.гггг). DOI: 10. 17805/ggz.2017.2.2

Башина, О. Э., Никоненко, В. Н. (2017) К вопросу о рациональной системе показателей состояния и развития научной сферы [Электронный ресурс] // Горизонты гуманитарного знания. № 5. URL: http://journals.mosgu.ru/ggz/article/view/598 (дата обращения: дд.мм.гггг). DOI: 10.17805/ggz.2017.5.2

Борисов, Г. А. (2017) Тезаурусная сфера и политический аудит [Электронный ресурс] // Горизонты гуманитарного знания. № 6. URL: http://journals.mosgu.ru/ggz/article/view/639 (дата обращения: дд.мм.Гггг). DOI: 10.17805/ggz.2017.6.3

Гаврилова, Е. В., Колесниченко, Л. И. (2017) Экологические аспекты жизни древних греков [Электронный ресурс] // Горизонты гуманитарного знания. № 3. URL: http://journals.mosgu.ru/ggz/article/view/514 (дата обращения: дд.мм.гггг). DOI: 10.17805/ggz.2017. 3.4

Гайдин, Б. Н. (2017а) Шекспир в кино: национальное и глобальное [Электронный ресурс] // Горизонты гуманитарного знания. № 5. URL: http://journals.mosgu.ru/ggz/article/view/606 (дата обращения: дд.мм.гггг). DOI: 10.17805/ggz.2017.5.9

Гайдин, Б. Н. (2017b) Шекспир в современной русской культуpe: национальное и глобальное [Электронный ресурс] // Горизонты гуманитарного знания. № 6. URL: http://journals.mosgu.ru/ggz/article/ view/640 (дата обращения: дд.мм.гггг). DOI: 10.17805/ggz.2017.6.4

Гайдин, Б. Н. (2017c) Онлайн-программа сравнительного тезаурусного анализа русских переводов произведений У. Шекспира: итоги первого года [Электронный ресурс] // Горизонты гуманитарного знания. № 6. URL: http://journals.mosgu.ru/ggz/article/view/649 (дата обращения: дд.мм.гггг). DOI: 10.17805/ggz.2017.6.10

Горелов, А. А., Горелова, Т. А. (2017) Современные императивы коэволюции человека и природы [Электронный ресурс] // Горизонты гуманитарного знания. № 4. URL: http://journals.mosgu.ru/ggz/ 
article/view/554 (дата обращения: дд.мм.гггг). DOI: 10.17805/ggz.2017 .4 .1

Гудима, Т. М. (2017) История, современное состояние и перспективы музеев России [Электронный ресурс] // Горизонты гуманитарного знания. № 3. URL: http://journals.mosgu.ru/ggz/article/view/ $\underline{518}$ (дата обращения: дд.мм.гггг). DOI: 10.17805/ggz.2017.3.8

Дугин, В. А., Луков, С. В. (2017) Публикации «Горизонтов гуманитарного знания» за 2017 год: итоги первого года [Электронный pecypc] // Горизонты гуманитарного знания. № 6. URL: http://journals. mosgu.ru/ggz/article/view/638 (дата обращения: дд.мм.гггг). DOI: 10. 17805/ggz.2017.6.2

Емельянова, Т. П., Дробышева, Т. В. (2017) Характеристики коллективной памяти в контексте социально-психологических особенностей двух поколений [Электронный ресурс] // Горизонты гуманитарного знания. № 5. URL: http://journals.mosgu.ru/ggz/article/view/ $\underline{603}$ (дата обращения: дд.мм.гггг). DOI: 10.17805/ggz.2017.5.6

Завьялова, Н. А. (2017) Пограничные зоны в сознании японцев: опыт интерпретации культурных языковых единиц [Электронный pecypc] // Горизонты гуманитарного знания. № 2. URL: http://journals. mosgu.ru/ggz/article/view/459 (дата обращения: дд.мм.гггг). DOI: 10. 17805/ggz.2017.2.8

Захаров, Н. В. (2017) Сравнительный анализ русских переводов первой сцены «Меры за меру» У. Шекспира [Электронный ресурс] // Горизонты гуманитарного знания. № 6. URL: http://journals. mosgu.ru/ggz/article/view/646 (дата обращения: дд.мм.гггг). DOI: 10. 17805/ggz.2017.6.7

Иванова, И. С. (2017) Этическое и эстетическое отношение к природе в различных культурах и религиях [Электронный ресурс] // Горизонты гуманитарного знания. № 4. URL: http://journals.mosgu.ru/ ggz/article/view/583 (дата обращения: дд.мм.гггг). DOI: 10.17805/ ggz.2017.4.8

Ильин, А. Н. (2017а) Френсис Фукуяма: ради идеологически нагруженной русофобии все средства хороши [Электронный ресурс] // Горизонты гуманитарного знания. № 2. URL: http://journals.mosgu. ru/ggz/article/view/461 (дата обращения: дд.мм.гггг). DOI: 10.17805/ ggz.2017.2.4

Ильин, А. Н. (2017b) США: безответственная риторика и вероломная политика [Электронный ресурс] // Горизонты гуманитарного 
знания. № 5. URL: http://journals.mosgu.ru/ggz/article/view/602 (дата обращения: дд.мм.гггг). DOI: 10.17805/ggz.2017.5.5

Именнова, Л. С. (2017) Природа как источник символической деятельности [Электронный ресурс] // Горизонты гуманитарного знания. № 4. URL: http://journals.mosgu.ru/ggz/article/view/581 (дата обращения: дд.мм.гггг). DOI: 10.17805/ggz.2017.4.6

Июдин, Д. А. (2017) Вечные образы Ромео и Джульетты в тезаурусе молодежи [Электронный ресурс] // Горизонты гуманитарного знания. № 6. URL: http://journals.mosgu.ru/ggz/article/view/641 (дата обращения: дд.мм.гггг). DOI: 10.17805/ggz.2017.6.5

Калита, С. П. (2017) Уровни охраны природного наследия: взгляд культуролога [Электронный ресурс] // Горизонты гуманитарного знания. № 3. URL: http://journals.mosgu.ru/ggz/article/view/515 (дата обращения: дд.мм.гггг). DOI: 10.17805/ggz.2017.3.5

Канарш, Г. Ю. (2017) Национально-психологические особенности в процессах модернизации [Электронный ресурс] // Горизонты гуманитарного знания. № 5. URL: http://journals.mosgu.ru/ggz/article/ view/601 (дата обращения: дд.мм.гггг). DOI 10.17805/ggz.2017.5.4

Кожаринова, А. Р. (2017) Мусор как продукт культуры: от утилизации к эстетизации [Электронный ресурс] // Горизонты гуманитарного знания. № 3. URL: http://journals.mosgu.ru/ggz/article/view/ $\underline{520}$ (дата обращения: дд.мм.гггг). DOI: 10.17805/ggz.2017.3.10

Козьякова М. И. (2017) Экологический тренд как вектор развития [Электронный ресурс] // Горизонты гуманитарного знания. № 3. URL: http://journals.mosgu.ru/ggz/article/view/519 (дата обращения: дд.мм.гггг). DOI: 10.17805/ggz.2017.3.9

Комолов, О. Е. (2017) Соотношение тревожности и мотивационных диспозиций у лиц с ограниченными возможностями здоровья [Электронный ресурс] // Горизонты гуманитарного знания. № 1. URL: http://journals.mosgu.ru/ggz/article/view/443 (дата обращения: дд.мм.гггг). DOI: 10.17805/ggz.2017.1.4

Кузнецова, Т. Ф. (2017) Субъектность как атрибут экологии культуры [Электронный ресурс] // Горизонты гуманитарного знания. № 4. URL: http://journals.mosgu.ru/ggz/article/view/576 (дата обращения: дд.мм.гггг). DOI: 10.17805/ggz.2017.4.4

Кузьмичев, А. И. (2017) Пьесы У. Шекспира в советском театре и кинематографе (по материалам «Шекспировских чтений»). Часть I. Концепция «ренессансного» Шекспира [Электронный ресурс] // Го- 
ризонты гуманитарного знания. № 6. URL: http://journals.mosgu.ru/ ggz/article/view/648 (дата обращения: дд.мм.гггг). DOI: 10.17805/ggz. 2017.6.5

Кулешова, М. Е. (2017) Формы охраны природно-культурного наследия и категория культурного ландшафта [Электронный ресурс] // Горизонты гуманитарного знания. № 4. URL: http://journals.mosgu. ru/ggz/article/view/580 (дата обращения: дд.мм.гггг). DOI: 10.17805/ ggz.2017.4.5

Ламажаа, Ч. К. (2017) Человек этнический: проблемы конструирования [Электронный ресурс] // Горизонты гуманитарного знания. № 4. URL: http://journals.mosgu.ru/ggz/article/view/555 (дата обращения: дд.мм.гггг). DOI: 10.17805/ggz.2017.4.2

Лисович, И. И. (2017) «Макбет» У. Шекспира и проблема вариативности русских переводов 30-60 гг. XX века [Электронный ресурс] // Горизонты гуманитарного знания. № 6. URL: http://journals. mosgu.ru/ggz/article/view/647 (дата обращения: дд.мм.гггг). DOI: 10. 17805/ggz.2017.6.8

Луков, В. А. (2017а) Горизонты гуманитарного знания: перспективы нового издания [Электронный ресурс] // Горизонты гуманитарного знания. № 1. URL: http://journals.mosgu.ru/ggz/article/view/ 441 (дата обращения: дд.мм.гггг). DOI: 10.17805/ggz.2017.1.1

Луков, В. А. (2017b) Пограничные зоны человеческого существования и их осознание человеком [Электронный ресурс] // Горизонты гуманитарного знания. № 2. URL: http://journals.mosgu.ru/ggz/ article/view/457 (дата обращения: дд.мм.гггг). DOI: 10.17805/ggz. 2017.2.1

Луков, В. А. (2017c) Экология культуры и тезаурусная трактовка будущего [Электронный ресурс] // Горизонты гуманитарного знания. № 3. URL: http://journals.mosgu.ru/ggz/article/view/511 (дата обращения: дд.мм.гггг). DOI: 10.17805/ggz.2017.3.1

Луков, В. А. (2017d) Разделение наук о природе и наук о культуре в Баденской школе неокантианства и перспективы исследований молодежи [Электронный ресурс] // Горизонты гуманитарного знания.№ 5. URL: http://journals.mosgu.ru/ggz/article/view/597 (дата обращения: дд.мм.гггг). DOI: 10.17805/ggz.2017.5.1

Луков, В. А. (2017е) Полевой и сферный подходы в гуманитарных науках [Электронный ресурс] // Горизонты гуманитарного знания. № 6. URL: http://journals.mosgu.ru/ggz/article/view/637 (дата об- 
ращения: дд.мм.гггг). DOI: 10.17805/ggz.2017.6.1

Луков, В. А., Луков, С. В. (2017) Адаптация к учебе в вузе отдельных проблемных групп первокурсников: эмпирические данные и теоретические выводы [Электронный ресурс] // Горизонты гуманитарного знания. № 5. URL: http://journals.mosgu.ru/ggz/article/view/ 604 (дата обращения: дд.мм.гггг). DOI: 10.17805/ggz.2017.5.7

Луков, В. А., Погорский, Э. К. (2017) Синтез данных об эффективности принятых инициатив в образовании [Электронный ресурс] // Горизонты гуманитарного знания. № 5. URL: http://journals.mosgu. ru/ggz/article/view/600 (дата обращения: дд.мм.гггг). DOI: 10.17805/ ggz.2017.5.3

Луков, Вл. А. (2017) Экология культуры и тезаурусные технологии преодоления глобализационной энтропии знаний [Электронный pecypc] // Горизонты гуманитарного знания. № 4. URL: http://journals.mosgu.ru/ggz/article/view/585 (дата обращения: дд.мм. гггг). DOI: 10.17805/ggz.2017.4.10

Луков, С. В. (2017а) О тематике воспитания молодежи на страницах журнала «Знание. Понимание. Умение» (2012-2016 гг.) [Электронный ресурс] // Горизонты гуманитарного знания. № 1. URL: http://journals.mosgu.ru/ggz/article/view/442 (дата обращения: дд.мм. гггг). DOI: 10.17805/ggz.2017.1.2

Луков, С. В. (2017b) Искусственный интеллект и киберпространство [Электронный ресурс] // Горизонты гуманитарного знания. № 2. URL: http://journals.mosgu.ru/ggz/article/view/464 (дата обращения: дд.мм.гггг). DOI: 10.17805/ggz.2017.2.7

Макаревич, Э. Ф. (2017) Некоторые вопросы гуманитарного сопротивления глобальному контролю масс [Электронный ресурс] // Горизонты гуманитарного знания. № 4. URL: http://journals.mosgu.ru/ ggz/article/view/584 (дата обращения: дд.мм.гггг). DOI: 10.17805/ggz. 2017.4.9

Макаров, В. С. (2017) «Бесплодные усилия любви» в русских переводах: опыт сравнительного анализа [Электронный ресурс] // Горизонты гуманитарного знания. № 6. URL: http://journals.mosgu.ru/ ggz/article/view/642 (дата обращения: дд.мм.гггг). DOI: 10.17805/ggz. 2017.6.6

Меняева, М. П., Невелева, В. С. (2017) Социокультурная парадигма согласия как основа стратегии будущего [Электронный ресурс] // Горизонты гуманитарного знания. № 3. URL: http://journals. 
mosgu.ru/ggz/article/view/516 (дата обращения: дд.мм.гггг). DOI: 10. 17805/ggz.2017.3.6

Науменко, В. Г. (2017) «...Везде один за всех...» Памяти Светлейшего Князя Потемкина-Таврического [Электронный ресурс] // Горизонты гуманитарного знания. № 2. URL: http://journals.mosgu.ru/ ggz/article/view/460 (дата обращения: дд.мм.гггг). DOI: 10.17805/ggz. 2017.2.3

Пинчук, А. Н. (2017) Культурный капитал семьи как условие формирования габитуса учащегося [Электронный ресурс] // Горизонты гуманитарного знания. № 1. URL: http://journals.mosgu.ru/ggz/article/view/444 (дата обращения: дд.мм.гггг). DOI: 10.17805/ggz.2017. 1.6

Сальникова, Е. В. (2017) Кризис и катастрофа экосистемы в советской кинофантастике [Электронный ресурс] // Горизонты гуманитарного знания. № 3. URL: http://journals.mosgu.ru/ggz/article/view/ 517 (дата обращения: дд.мм.гггг). DOI: 10.17805/ggz.2017.3.7

Семериков, В. А. (2017) Особенности эмоциональных состояний у студентов с ограниченными возможностями здоровья [Электронный ресурс] // Горизонты гуманитарного знания. № 1. URL: http://journals.mosgu.ru/ggz/article/view/445 (дата обращения: дд.мм. гггг). DOI: 10.17805/ggz.2017.1.5

Тихомиров, Д. А., Кисткина, И. А. (2017) Проблема осознания экологической угрозы в России [Электронный ресурс] // Горизонты гуманитарного знания. № 2. URL: http://journals.mosgu.ru/ggz/article/ view/462 (дата обращения: дд.мм.гггг). DOI: 10.17805/ggz.2017.2.5

Тихомиров, Д. А., Сиднева, Е. В. (2017) Оценка выпускниками московских вузов социально-гуманитарного профиля своего образования и перспектив трудоустройства [Электронный ресурс] // Горизонты гуманитарного знания. № 4. URL: http://journals.mosgu.ru/ ggz/article/view/582 (дата обращения: дд.мм.гггг). DOI: 10.17805/ggz. 2017.4.7

Торос, Д. Е., Колесниченко, Л. И. (2017) Трансформация ментальности римского гражданина в период складывания вертикали власти эпохи принципата [Электронный ресурс] // Горизонты гуманитарного знания. № 4. URL: http://journals.mosgu.ru/ggz/article/view/ 556 (дата обращения: дд.мм.гггг). DOI: 10.17805/ggz.2017.4.3

Турбовской Я. С. (2017) Будущее как объект философскопедагогического осмысления [Электронный ресурс] // Горизонты гу- 
манитарного знания. № 3. URL: http://journals.mosgu.ru/ggz/article/ view/512 (дата обращения: дд.мм.гггг). DOI: 10.17805/ggz.2017.3.2

Флиер, А. Я. (2017) Классическая, неклассическая и постнеклассическая культуры: опыт новой типологии [Электронный ресурс] // Горизонты гуманитарного знания. № 3. URL: http://journals. mosgu.ru/ggz/article/view/513 (дата обращения: дд.мм.гггг). DOI: 10. 17805/ggz.2017.3.3

Шонин, М. Ю. (2017) О формировании познавательного интереса в процессе обучения [Электронный ресурс] // Горизонты гуманитарного знания. № 1. URL: http://journals.mosgu.ru/ggz/article/view/ 446 (дата обращения: дд.мм.гггг). DOI: 10.17805/ggz.2017.1.3

Юдин, Б. Г. (2017) О теоретико-методологических основаниях биосоциологии [Электронный ресурс] // Горизонты гуманитарного знания. № 5. URL: http://journals.mosgu.ru/ggz/article/view/605 (дата обращения: дд.мм.гггг). DOI: 10.17805/ggz.2017.5.8

Ярославцева, Е. И. (2017) Экоустойчивость человека и динамичность цифрового мира [Электронный ресурс] // Горизонты гуманитарного знания. № 2. URL: http://journals.mosgu.ru/ggz/article/view/ 463 (дата обращения: дд.мм.гггг). DOI: 10.17805/ggz.2017.2.6

Дата поступления: 28.12.2017 г.

Дугин Владислав Андреевич - студент Московского гуманитарного университета. Адрес: 111395, Россия, г. Москва, ул. Юности, 5. Тел.: +7 (499) 374-75-95. Эл. адрес: duginseva@gmail.com

Dugin Vladislav Andreevich, student, Moscow University for the Humanities. Postal address: 5 Yunosti St., 111395 Moscow, Russian Federation. Tel.: +7 (499) 374-75-95. E-mail: duginseva@gmail.com

Луков Сергей Валерьевич - кандидат социологических наук, магистр социальной работы (Германия), начальник отдела прикладной социологии Центра социологии молодежи Института фундаментальных и прикладных исследований Московского гуманитарного университета. Адрес: 111395, Россия, г. Москва, ул. Юности, 5. Тел.: +7 (499) 374-75-95. Эл. адрес: sv-lukov@ mail.ru 
Lukov Sergey Valerievich, Candidate of Sociological Sciences, Master of Social Work (Germany), Head, Department of Applied Sociology, Centre for Sociology of Youth, Institute for Fundamental and Applied Studies, Moscow University for the Humanities. Postal address: 5 Yunosti St., 111395 Moscow, Russian Federation. Tel.: +7 (499) 374-7595. E-mail: $\underline{\text { sv-lukov@mail.ru }}$

\section{Для ичитирования:}

Дугин В. А., Луков С. В. Публикации «Горизонтов гуманитарного знания» за 2017 год: итоги первого года [Электронный ресурс] // Горизонты гуманитарного знания. 2017. № 6. С. 16-36. URL: http://journals.mosgu.ru/ggz/article/view/638 (дата обращения: дд.мм. гггг). DOI: 10.17805/ggz.2017.6.2 